\title{
Higher Education in the Era of Globalisation: A Case Study of Andhra Pradesh
}

\author{
Dr. E. Raju \\ Post Doctoral Fellow, Dept Of Economics, Acharya Nagarjuna University, Guntur, A.P., India
}

\begin{abstract}
Higher Education in India is one of the largest and oldest systems of higher education found anywhere in the world. As of now there are 320 Universities, of which nearly 131 are of Affiliating Universities. Besides there are deemed universities, institutions of national importance, institutes and over 15500 colleges. The higher education system in India has constantly striven to build new college as places of culture and of learning open to all and, above all, reinforcing the theme of learning throughout life, participating in and contributing to major debates concerning the direction and future of society is seen as a major task, and a moral obligation as well, of the colleges system. India has had a long tradition of inquiry and articulation of concepts of colleges, self, role of state, economy, social order and other related matters. The methodologies adopted were subjective and objective and included observation, conceptualization, verification, articulation and teaching. The higher education system in India recognize its key responsibility in training teachers, in establishing links with teacher training institutions at other levels and in training teacher trainers. Efforts are being made to bring in teachers from the commercial and social sectors to facilitate interchange and build links with the education system. The secondary education system in India is facilitating access to the common heritage of knowledge and research. It is fulfilling its moral obligation to society in exchange for the resources assigned to it by society. Recently, a task Force on Fundamental Duties laid down in the constitution has been constituted so that the same can be reflected in the curriculum. This would also lay down a code of accountability of all takeholders in the educational system. The main objectives of the Paper are study higher education in Andhra Pradesh, to study the extent of higher education in rural and urban areas in Andhra Pradesh.
\end{abstract}

Our university system is, in many parts, in a state of disrepair...In almost half the districts in the country, higher education enrollments are abysmally low, almost two-third of our universities and 90 per cent of our colleges are rated as below average on quality parameters... I am concerned that in many states university appointments, including that of Vice-chancellors, have been politicized and have become subject to caste and communal considerations, there are complaints of favoritism and corruption.

Higher Education in India is one of the largest and oldest systems of higher education found anywhere in the world. As of now there are 320 Universities, of which nearly 131 are of Affiliating Universities. Besides there are deemed universities, institutions of national importance, institutes and over 15500 colleges. Together they offer a wide range of degree and diploma programs across the length and breadth of the country. The higher education system in India has constantly striven to build new college as places of culture and of learning open to all and, above all, reinforcing the theme of learning throughout life, participating in and contributing to major debates concerning the direction and future of society is seen as a major task, and a moral obligation as well, of the colleges system. India has had a long tradition of inquiry and articulation of concepts of colleges, self, role of state, economy, social order and other related matters. The methodologies adopted were subjective and objective and included observation, conceptualization, verification, articulation and teaching. The higher education system in India recognize its key responsibility in training teachers, in establishing links with teacher training institutions at other levels and in training teacher trainers. Efforts are being made to bring in teachers from the commercial and social sectors to facilitate interchange and build links with the education system. The secondary education system in India is facilitating access to the common heritage of knowledge and research. It is fulfilling its moral obligation to society in exchange for the resources assigned to it by society. Recently, a task Force on Fundamental Duties laid down in the constitution has been constituted so that the same can be reflected in the curriculum. This would also lay down a code of accountability of all stakeholders in the educational system.

\footnotetext{
${ }^{1}$ Prime Minister Manmohan Singh in 2007
} 


\section{Mission of Higher Education}

The mission of higher education is to achieve access, equality, justice, quality, employability, inclusiveness and create a knowledge society economy. To increase access, the number of institutions in the country must double in the next five years. More universities must come up from central government and the existing universities must be developed. Also, programs that allow shift system of education (morning and evening shifts), evening PG programs and integrated UG/ PG programs would help the cause of access to higher education. There should be about $20 \%$ to $30 \%$ increase in intake of students every year. In order to improve the areas of research, it is necessary to upgrade laboratories, motivate researchers and provide research funding. International collaboration of research must be promoted and the researchers must be released from undue restrictions on international travel. There should be enhanced participation rates in higher education from girls, SC/ST students, minorities and physically handicapped.

\section{The main objectives of the Paper are:}

- To study higher education in Andhra Pradesh.

- To study the extent of higher education in rural and urban areas in Andhra Pradesh

World Development Report 2007 the conventional wisdom on the role of education in economic development is being revised in terms of both theory and new evidence from India and other developing countries. Tertiary education is now considered critical from the standpoint of achieving overall economic and social development. In many developing countries earnings of workers with higher education have risen substantially unlike in the past. In Latin America and the Caribbean, labour market returns to those who completed primary or secondary education have declined sharply while the returns to those with tertiary education have improved

Tilak Nov, 2005 in words of education in general and higher education in particular, which ensures availability of manpower of right quantity and quality for all activities including health and education, has to be the equalizer on an otherwise efficiency driven market economy. "The externalities of education, including the dynamic externalities of higher education are indeed immense and they have profound positive effect on economic growth"

Amartya Sen 2005 we in Indian should aim for a substantial increase in these ratios to lay a strong foundation for national economic prosperity and equitable development. "The importance of nonsectarian and non parochial school education that expands rather than reduces the reach of reasoning would be hard to exaggerate"

\section{Performance of Universities \& Colleges}

Quality assessment in higher education is of global interest government and public demand for accountability from higher education institution has steadily increased over the past decade. Quality assessment is frequently undertaken in response to external authorities who expect clear, ratified criteria to be used in the accountability process. If the assessment is to be beneficial, change must be effected from within the institution. This means that administrators, faculty members, and students also need an understanding of the criteria that can guide and facilitate improvements in the way they function. Thus to be both valid and useful, the approach taken to assessment must be aligned or consistent with the goals of the institution assessment must be credible and incorporated.

\section{Status of Higher Education in India}

Since Independence higher education has grown in the country substantially. Now there are approximately 652 universities, 28,000 colleges, within estimated 106 lakh students enrolled in the higher education institutions. Merely increasing the number of higher educated institutions and their enrolment capacity will not achieve the national system, its access to those who desire, and equity measures ensuring fait and important treatment of the disadvantaged sections of the society.

Table-1 Distribution of universities \& University Level Institution in India

\begin{tabular}{|l|l|l|}
\hline Type of University & India (As on 17-09-2012) & Percentage \\
\hline State University & 299 & 46 \\
\hline Private University & 140 & 21 \\
\hline Institution of National Importance & 39 & 6 \\
\hline Deemed University & 130 & 20 \\
\hline Central University & 44 & 7 \\
\hline Total & 652 & 100 \\
\hline
\end{tabular}

Source of Data: UGC 
The expansion of higher education without maintaining quality in not desirable. The quality is first essential requirement for an institution. It is more so in case of higher education institutions because it is where the youth is shaped. There is a growing concern for quality and those who positively respond to this will survives and prosper. Hence there is a dire need to enhance and maintain quality in our educational institutions. It is in this context of deterioration in quality, that the National Policy on Education, 1986 and the Plan of Action, 1992 spelt out the strategic plans for the education policies, and advocated the establishment of an independent national accredition organization for higher education. To fulfill this need the National Assessment and Accreditation Council (NAAC) was established at Bangalore in 1994 by the university Grants Commission to Assess and Accredit institutions of higher education in the country. It is an external quality Assurance Agency like the higher Education Quality Control Council of the UK and is a member of the International Network of Quality Assurance Agencies in higher Education (INQAAHE)

Table-2 Growth of Institutions in the Eleventh Plan

\begin{tabular}{|c|c|c|c|c|}
\hline Category & $2006-07$ & 2011-12 & Increase & Growth Rate $(\%)$ \\
\hline \multicolumn{5}{|l|}{ Central Institutions } \\
\hline Degree Awarding Institutions & 75 & 138 & 63 & 13.0 \\
\hline Colleges & 58 & 69 & 11 & 3.5 \\
\hline Diploma Institutions & 14 & 24 & 10 & 11.4 \\
\hline Sub Total & 147 & 231 & 84 & 9.5 \\
\hline \multicolumn{5}{|l|}{ State Institutions } \\
\hline Degree Awarding Institutions & 253 & 316 & 63 & 4.5 \\
\hline Colleges & 9,500 & 13,024 & 3,524 & 6.5 \\
\hline Diploma Institutions & 2,151 & 3207 & 1,056 & 8.3 \\
\hline Sub Total & 11,904 & 16,547 & 4,643 & 6.8 \\
\hline \multicolumn{5}{|l|}{ Private Institutions } \\
\hline Degree Awarding Institutions & 80 & 191 & 111 & 19.0 \\
\hline Colleges & 13,706 & 19,930 & 6,224 & 7.8 \\
\hline Diploma Institutions & 7,220 & 9,541 & 2,321 & 5.7 \\
\hline Sub Total & 21,006 & 29,662 & 8,656 & 7.2 \\
\hline Total & $\mathbf{3 3 , 0 5 7}$ & 46,446 & 13,383 & 7.0 \\
\hline
\end{tabular}

Source of the Data: MoHRD, UGC

Above Table- 2 came into being as a state of the union of India. As a result of the merger of five territories where Telugu was the language of the people. The above table shows about the particulars of "Growth of Institutions in the Eleventh Plan". Growth rate of Central Level Degree awarianing institutions is 13 per cent growth rate of central level colleges is 3.5 per cent and growth rate of central level diploma level diploma institutions is 11.4 per cent, totally subtotal growth rate is 9.5 per cent. While, growth rate of state level degree awarding institutions is 4.5 per cent, growth rate of state level colleges is 6.5 per cent and growth rate of state level diploma institutions is 8.3 per cent growth rate of private level degree awarding institutions is 19 per cent, growth rate of private level colleges is 7.8 per cent, and growth rate of diploma institutions is 5.7 per cent. Finally concluded that above the table central level institutions are high growth rate and then lower growth rate central to state level institutions.

\section{Results and Discussions:}

Table-3 Status of affiliated Degree Colleges in Andhra Pradesh

\begin{tabular}{|l|l|l|}
\hline S.No & Name of the Universities & No. of University affiliated Colleges in A.P \\
\hline 1 & Osmania University & 99 \\
\hline 2 & Palamuru University & 8 \\
\hline 3 & Kakatiya University & 25 \\
\hline 4 & Satavahana University & 14 \\
\hline 5 & Andhra University & 19 \\
\hline 6 & Dr.B.R.Ambedkar University & 10 \\
\hline 7 & Acharya Nagarjuna University & 11 \\
\hline 8 & Krishna University & 5 \\
\hline 9 & Sri Venkateswara University & 14 \\
\hline 10 & Vikrama Simbapuri University & 8 \\
\hline 11 & Yogi Vemana University & 7 \\
\hline 12 & Sri Krsishnadevearaya University & 2 \\
\hline Total & & 222 \\
\hline
\end{tabular}

Source: Survey Data

Above table -3 shows that status of unaided degree colleges in Andhra Pradesh. The Table denoted that number of university affiliated colleges in Andhra Pradesh. Osmania University has highest affiliated colleges in AP(99), Kakatiya University has affiliated colleges are 25, Andhra University has 19, Satavahana University 
and Sri Venkateswara Universities have 14 colleges, lowest colleges concerned to Sri Krishnadevaraya university.

Table-4 Unaided Degree Colleges Area Wise in Andhra Pradesh

\begin{tabular}{|l|l|l|l|l|}
\hline Year & Urban & Rural & Tribal & Total \\
\hline $2006-07$ & 13 & 45 & 5 & 63 \\
\hline $2007-08$ & 4 & 53 & 4 & 61 \\
\hline $2008-09$ & 12 & 66 & 3 & 81 \\
\hline $2009-10$ & 5 & 37 & 2 & 44 \\
\hline $2010-11$ & 9 & 68 & 1 & 68 \\
\hline $2011-12$ & 29 & 61 & 8 & 98 \\
\hline
\end{tabular}

Source: Survey Data

The Table-4 indicates that the unaided degree colleges area wise in Andhra Pradesh, during the period 2006-12, unaided degree colleges are located in urban, rural and Tribal areas, in 2011-12, unaided degree colleges in urban area are 29, 13 colleges in 2006-07, and 12 colleges in 2008-09. In Rural area, 66 colleges in 2008-09, 58 in 2010-11, 53 in 2007-08. In Tribal area, 8 colleges in 2011-12, 5 colleges in 2006-07, and only one college in 2010-11. Totally concluded that table 98 unaided degree colleges in 2011-12, lowest unaided degree colleges in 2009-10 are 44.

Table-5 District-Wise SC.Candidates qualified in the Higher Education in Andhra Pradesh 2011-12

\begin{tabular}{|c|c|c|c|c|}
\hline S.No & Name of the District & Male & Female & Total \\
\hline 1 & Srikakulam & 6912 & 6956 & 13870 \\
\hline 2 & Vizianagaram & 7239 & 7137 & 14378 \\
\hline 3 & Visakhapatnam & 8922 & 8668 & 17591 \\
\hline 5 & West Godavari & 22314 & 21719 & 44034 \\
\hline 6 & Krishna & 22993 & 22121 & 45114 \\
\hline 7 & Guntur & 25205 & 24209 & 49413 \\
\hline 9 & Nellore & 17968 & 17499 & 35468 \\
\hline 10 & Chittoor & 21480 & 20943 & 42425 \\
\hline 11 & Cuddapah & 12599 & 12137 & 24736 \\
\hline 12 & Anantapur & 16002 & 15103 & 31103 \\
\hline 13 & Kurnool & 19478 & 18497 & 37974 \\
\hline 14 & Mahabubnagar & 18514 & 17786 & 36300 \\
\hline 18 & Nizamabad & 10344 & 10682 & 21031 \\
\hline 19 & Adilabad & 14087 & 13771 & 27860 \\
\hline 20 & Karimnagar & 19802 & 19474 & 39279 \\
\hline 21 & Warngal & 17012 & 16296 & 33307 \\
\hline 22 & Khammam & 13173 & 12602 & 25775 \\
\hline 23 & Nalgonda & 17744 & 17038 & 34782 \\
\hline \multicolumn{2}{|l|}{ Total } & 378522 & 366871 & 745401 \\
\hline
\end{tabular}

Source: Survey Data

Above Table-5 District-Wise SC candidates qualified in the higher education in Andhra Pradesh, on comparing the types of District facilitate availed for the education in Andhra Pradesh higher education in more qualification in 53,258 in East Godavari, male ratio is 26,883 and Female 26,372. Lowest rate of Srikakulam 13,870 occupied. Further it was observed that the higher education in the male ratio is $3,78,533$ and Female $3.66,871$. It is going to increasing ratio.

Table-6District-Wise ST.Candidates qualified in the Higher Education in Andhra Pradesh 2011-12

\begin{tabular}{|l|l|l|l|l|}
\hline S.No & Name of the District & Male & Female & Total \\
\hline 1 & Srikakulam & 4575 & 4560 & 9136 \\
\hline 2 & Vizianagaram & 6447 & 6528 & 12977 \\
\hline 3 & Visakhapatnam & 16920 & 16758 & 33681 \\
\hline 4 & East Godavari & 5788 & 5782 & 11571 \\
\hline 5 & West Godavari & 2910 & 2827 & 5838 \\
\hline 6 & Krishna & 3354 & 3146 & 6500 \\
\hline 7 & Guntur & 6448 & 6126 & 12574 \\
\hline 8 & Prakasam & 3687 & 3455 & 7142 \\
\hline 9 & Nellore & 7509 & 7125 & 14634 \\
\hline 10 & Chittoor & 3953 & 3784 & 7737 \\
\hline
\end{tabular}


Higher Education in the Era of Globalisation: A Case Study of Andhra Pradesh

\begin{tabular}{|l|l|l|l|l|}
\hline 11 & Cuddapah & 1923 & 1784 & 3707 \\
\hline 12 & Anantapur & 3994 & 3688 & 7681 \\
\hline 13 & Kurnool & 2193 & 2013 & 4206 \\
\hline 14 & Mahabubnagar & 8698 & 8139 & 16835 \\
\hline 15 & Rangareddy & 4561 & 4262 & 8822 \\
\hline 16 & Hyderabad & 1085 & 1002 & 2087 \\
\hline 17 & Medak & 4191 & 3935 & 8126 \\
\hline 18 & Nizamabad & 5052 & 4958 & 10011 \\
\hline 19 & Adilabad & 12737 & 12421 & 25160 \\
\hline 20 & Karimnagar & 2784 & 2691 & 5475 \\
\hline 21 & Warangal & 14310 & 13340 & 27647 \\
\hline 22 & Khammam & 20908 & 20325 & 41235 \\
\hline 23 & Nalgonda & 10840 & 9863 & 20700 \\
\hline Total & & $\mathbf{1 5 4 8 7 8}$ & $\mathbf{1 4 8 6 2 2}$ & $\mathbf{3 0 3 4 9 4}$ \\
\hline
\end{tabular}

Source: Survey Data

Above the table denoted that district-wise qualified candidates in higher education in AP during the period 2011-12, in ST category. Male candidates are highest qualified in Khammam district is 20,908 and lowest qualified candidates in Hyderabad is 1085, while, female candidates are highest qualified in Khammam is 20,325 and lowest qualified in Hyderabad is 1002 . Finally concluded that table male and female candidates are qualified in higher education in ST category in khammam district is highest and lowest qualified in Hyderabad district in 2011-12.

Table-7 District - Wise Male Literacy Rate (\%) in Andhra Pradesh 2011-12

\begin{tabular}{|l|l|l|l|}
\hline S.No & Name of the District & Rural & Urban \\
\hline 1 & Srikakulam & $66.01 \%$ & $84.28 \%$ \\
\hline 2 & Vizianagaram & $68.66 \%$ & $85.78 \%$ \\
\hline 3 & Visakhapatnam & $70.65 \%$ & $86.15 \%$ \\
\hline 4 & East Godavari & $67.94 \%$ & $86.68 \%$ \\
\hline 5 & West Godavari & 0.00 & $83.35 \%$ \\
\hline 6 & Krishna & $71.69 \%$ & $89.10 \%$ \\
\hline 7 & Guntur & $62.66 \%$ & $86.23 \%$ \\
\hline 8 & Prakasam & $71.62 \%$ & $89.08 \%$ \\
\hline 9 & Nellore & $70.51 \%$ & $89.42 \%$ \\
\hline 10 & Chittoor & $68.84 \%$ & $87.51 \%$ \\
\hline 11 & Cuddapah & $69.50 \%$ & $86.57 \%$ \\
\hline 12 & Anantapur & $64.60 \%$ & $85.89 \%$ \\
\hline 13 & Kurnool & $64.00 \%$ & $87.67 \%$ \\
\hline 14 & Mahabubnagar & $71.48 \%$ & $84.98 \%$ \\
\hline 15 & Rangareddy & $75.79 \%$ & $84.82 \%$ \\
\hline 16 & Hyderabad & $74.35 \%$ & $85.96 \%$ \\
\hline 17 & Medak & $70.80 \%$ & $84.41 \%$ \\
\hline 18 & Nizamabad & $70.39 \%$ & $86.49 \%$ \\
\hline 19 & Adilabad & $71.68 \%$ & $86.16 \%$ \\
\hline 20 & Karimnagar & $75.36 \%$ & $84.31 \%$ \\
\hline 21 & Warangal & $67.52 \%$ & $81.04 \%$ \\
\hline 22 & Khammam & $70.41 \%$ & $83.56 \%$ \\
\hline 23 & Nalgonda & $77.73 \%$ & $89.26 \%$ \\
\hline$D a t$ & & & \\
\hline
\end{tabular}

Source: Survey Data

Above the table shows that district- wise male literacy rate in AP in 2011-12. According to table reveals that male rural in and urban areas. In rural area, Nalgonda district has highest Male literacy, rate is 77.73 per cent cent and lowest male literacy rate is 62.66 per cent in Guntur district. In urban areas, Nellore district has highest male literacy rate is 89.42 per cent and lowest male literacy rate is 81.04 per cent in Warangal district. Finally concluded that table reveals Nalgonda district has highest male literacy in rural area and urban areas and lowest male literacy in rural and urban areas in Guntur district.

Table-8District - Wise Female Literacy Rate (\%) in Andhra Pradesh 2011-12

\begin{tabular}{|l|l|l|l|}
\hline S.No & Name of the District & Rural & Urban \\
\hline 1 & Srikakulam & $45.67 \%$ & $98.48 \%$ \\
\hline 2 & Vizianagaram & $46.70 \%$ & $71.59 \%$ \\
\hline 3 & Visakhapatnam & $49.88 \%$ & $70.59 \%$ \\
\hline 4 & East Godavari & $46.37 \%$ & $72.23 \%$ \\
\hline 5 & West Godavari & 0.00 & $78.42 \%$ \\
\hline 6 & Krishna & $51.24 \%$ & $80.53 \%$ \\
\hline 7 & Guntur & $41.09 \%$ & $71.11 \%$ \\
\hline
\end{tabular}


Higher Education in the Era of Globalisation: A Case Study of Andhra Pradesh

\begin{tabular}{|l|l|l|l|}
\hline 8 & Prakasam & $50.24 \%$ & $75.28 \%$ \\
\hline 9 & Nellore & $49.49 \%$ & $74.04 \%$ \\
\hline 10 & Chittoor & $52.40 \%$ & $75.44 \%$ \\
\hline 11 & Cuddapah & $48.82 \%$ & $71.54 \%$ \\
\hline 12 & Anantapur & $44.28 \%$ & $71.85 \%$ \\
\hline 13 & Kurnool & $45.30 \%$ & $76.28 \%$ \\
\hline 14 & Mahabubnagar & $64.46 \%$ & $77.38 \%$ \\
\hline 15 & Rangareddy & $69.13 \%$ & $78.25 \%$ \\
\hline 16 & Hyderabad & $63.62 \%$ & $78.22 \%$ \\
\hline 17 & Medak & $54.27 \%$ & $72.85 \%$ \\
\hline 18 & Nizamabad & $48.86 \%$ & $71.64 \%$ \\
\hline 19 & Adilabad & $56.27 \%$ & $76.82 \%$ \\
\hline 20 & Karimnagar & $51.87 \%$ & $67.57 \%$ \\
\hline 21 & Warangal & $44.63 \%$ & $66.13 \%$ \\
\hline 22 & Khammam & $49.05 \%$ & $67.56 \%$ \\
\hline 23 & Nalgonda & $58.08 \%$ & $76.8 \%$ \\
\hline
\end{tabular}

Source: Survey Data

Above the table indicates that district wise female literacy rate in AP during the period 2011-12. The table reveals that female literacy rate in rural and urban areas. In rural areas, Rangareddy district has highest female literacy is 69.13 per cent and lowest female literacy is 41.09 per cent in Guntur district. In Urban areas, Srikakulam district has highest female literacy is 98.48 per cent and lowest literacy rate is 66.13 per cent in Warangal district. Finally concluded that table shows highest female literacy rate in Srikakulam district and lowest female literacy rate in Warngal district.

Table-9 Professional Colleges in Andhra Pradesh

\begin{tabular}{|l|l|l|}
\hline S.No & Name of the Course & Colleges in Andhra Pradesh \\
\hline 1 & Engineering & 306309 \\
\hline 2 & M.E/M.Tech & 23898 \\
\hline 3 & B.Pharmacy & 27240 \\
\hline 4 & MBA & 93231 \\
\hline 5 & MCA & 44530 \\
\hline 6 & M.Pharmacy & 9207 \\
\hline 7 & B.Ed. & 65018 \\
\hline 8 & B.Arc. & 925 \\
\hline 9 & B.PEd. & 760 \\
\hline 10 & U.G.D.P.Ed. & 665 \\
\hline 11 & LLM & 781 \\
\hline 12 & 3 years LLB & 7150 \\
\hline 13 & 5 years LLB & 2940 \\
\hline
\end{tabular}

Source: Survey Data

The table indicates that professional colleges in AP, period is 2011-12. The table reveals that number of colleges in professional course in AP. Highest number of colleges in Engineering course is 3, 06,309, next MBA course is 93, 231 colleges, 65,018 colleges for B.Ed, and 44,530 colleges for MCA courses. While, lowest number of colleges in U.G.D.P.Ed course is 665,760 colleges for B.PEd and 781 colleges for LLM. Finally concluded that table reveals highest priority colleges are preferred the courses are Engineering, MBA, MCA, and B.Ed courses.

Table-10 Status of the Students in qualified for Professional Courses for the year of 2011-12

\begin{tabular}{|l|l|l|}
\hline S.No & Name of the Course & No.of the Candidates qualified \\
\hline 1 & Engineering & $2,22,859$ \\
\hline 2 & M.E/M.Tech & 23,448 \\
\hline 3 & B.Pharmacy & 55,995 \\
\hline 4 & MBA & $1,26,454$ \\
\hline 5 & MCA & $1,36,456$ \\
\hline 6 & M.Pharmacy & 65,689 \\
\hline 7 & B.Ed. & $1,92,389$ \\
\hline 8 & B.Arc. & 67,891 \\
\hline 9 & B.PEd. & 36,213 \\
\hline 10 & U.G.D.P.Ed. & 26,136 \\
\hline 11 & LLM & 10,387 \\
\hline 12 & 3 years LLB & 2,196 \\
\hline 13 & 5 years LLB & $1,92,389$ \\
\hline
\end{tabular}

Source: Survey Data 
Above the table reveals that status of students in qualified for professional courses for the year 201112. $\mathrm{T}$ he table indicates that number of the candidates qualifies in professional course. Highest number of candidates qualified in engineering course is $2,22,859$, next same highest number of candidates qualified in B.Ed and 5 years LLB courses is 1,92,389 and lowest number of candidates qualified in 3 years LLB is 2,196. While, 1, 36,456 candidates qualified in MCA courses and 1, 26,456 candidates qualified in MBA courses. Finally concluded that table shows today highest priority candidates qualified in Engineering, 5 years LLB, B.Ed, MCA and MBA courses.

\section{Conclusion}

In India after independence, there has been tremendous increase in institutions of higher learning in all disciplines. But with the quantitative growth has it been able to attend to the core issue of quality. India is today one of the fastest developing countries of the world with the annual growth rate going above $9 \%$. In order to sustain that rate of growth, there is need to increase the number of institutes and also the quality of higher education in India. To reach and achieve the future requirements there is an urgent need to relook at the Financial Resource. With the advent of globalization the character of higher education is set of change. Higher education to be meaningful and productive must have avenues for excellence to flourish and develop. There will be a premium on quality with bench making of programmes assuming importance. The impact of technologies will progressively increase. So Indian universities need to look and a head and prepare themselves for far reaching changes. Unless the quality aspect is not taken care of the malady that exists in higher education will never be eliminated.

\section{References}

[1] Antonio, A. L. (2001b). The role of interracial interaction in the development of leadership skills and cultural knowledge and understanding. Research in Higher Education, 42(5), 593-617.

[2] Ross Williams and Nina Van Dyke J. (2004), The International Standing of Australian University, Melbourne: The Melbourne Institute of Applied Economic and Social Research, November 24.

[3] Amartya Sen (2006) Identity and Violence: The illusion of Destiny

[4] Asada, H., Swank, E., \& Goldey, G. T. (2003). The acceptance of a multicultural education among Appalachian college students. Research in Higher Education, 44(1), 99-120.

[5] Bowman, N. (2010a). College diversity experiences and cognitive development: A met analysis. Review of Educational Research, 80(1), 4-33.

[6] Brown, Alans (2006), "Enginners Well Prepared”, Mechanical Enfineering, August, Vol.128, No.8. PP 10-11.

[7] World Bank (2007), World Development Report- Development for Next Generation.

[8] Tilak JBG (2005) "Post Elementary Education Poverty and Development in India", working paper to Centre for African Studies, University of Edinburgh.

[9] Tilak, JBG (2005), "Higher Education in Thshanku": Hanging between State and Market, Economic and Political Weekly, September 10, P.4029-4037. 